\title{
NBN Gene Mutation
}

National Cancer Institute

\section{Source}

National Cancer Institute. NBN Gene Mutation. NCI Thesaurus. Code C131806.

A change in the nucleotide sequence of the NBN gene. 